\title{
河道の経年変化から見た樹林化の要因分析と 持続的な河川管理のための方策 ANALYSIS ON FORESTATION MECHANISM OF RIVER CHANNEL BASED ON MORPHOLOGICAL CHANGES AND STRATEGY FOR SUSTAINABLE RIVER MANAGEMENT
}

\author{
阿河一穂 $1 \cdot$ 道奥康治 $2 \cdot$ 神田佳一 $3 \cdot$ 魚谷拓矢 4 \\ Kazuho AGA, Kohji MICHIOKU, Keiichi KANDA, Takuya UOTANI \\ 1学生員, 2フェロー会員 工博 神戸大学大学院 工学研究科（†657-8501 神戸市灘区六甲台町1-1） \\ 3 正会員 博(工)，4学生員 明石工業高等専門学校（一674-8501明石市魚住町西岡679-3）
}

\begin{abstract}
Forestation on floodplain is now a world-wide issue from a river engineering viewpoint. Based on a field data analysis of river morphology, discharge and land cover in the last decades, a main cause of floodplain forestation was found to be decreased frequency of floodplain inundation after sequent channel restoration works. In order to perform an adaptive river management, a uniform flow analysis of vegetated channel is carried out for several cross sections from middle to downstream. It is investigated how floodplain excavation and thinning of tree vegetation modify flow structure and tree destruction during flood events. It is discussed based on the analysis what is a proper management strategy in order to create a safe and attractive river environment.
\end{abstract}

Key Words : vegetated channel, 1-D flow analysis, ecohydraulics, river management

\section{1.はじめに}

各国の河川において近年，樹林化・陸地化が進行し， 管理上の様々な課題をもたらしている. 過度な樹林化は 河積を侵して流水抵抗を増加させるとともに，流木を生 産するなど出水時の疎通障害を招く．自然環境面では樹 林部への土砂堆積・陸地化, 水際遷移帯の喪失, 生態系 の単調化，親水性の低下などの要因となる．河川本来の 治水・環境機能を再生・回復することが何よりも必要で あり, 樹林化の要因を分析し河川の持続的な管理戦略を 講ずる必要がある.

本研究で対象とする加古川の上中流には, 井堰が点在 するがダムなど大型の流量制御施設はなく，樹林化の主 たる要因として自然・人為の河川地形変化が疑われる. そこで，樹林化が顕在化する中下流部を対象に河川断面， 流量, 高水敷の冠水頻度など物理因子の経年変化を分析 し，河川地形と樹林化との因果関係を明らかにする.

次に，樹林化の抑制方策を考える. 河川地形の変化が 樹林化に寄与している場合には, 現状の河川地形を存置 する, あるいはこれまでと同様に整備し続けることは望 ましくない，伐採・伐木だけで樹林を制御することには， 河川管理や環境の持続性の観点から限界がある。このた め, 植生が適度な頻度で流水攪乱を受けながら更新され るように, 治水機能を維持しながら河川地形を再生し, 同時に最小限の樹林施業を加えて維持管理の省力化を図
らなければならない.このような [河川整備, 樹木管 理をを組み合わせた樹林化抑制の考え方は, ダムの流量 制御によって陸地化・植生繁茂が進む河川1 $に$ 対しても 適用可能と考えられる.

著者ら゙は樹林が繁茂した河川流を観測し，平面二次 元解析モデルによってここ数年間に発生した出水流況や 樹木倒伏実績を再現した. 二次元モデルは出水時におけ る流速や流体力の時間的推移の詳細情報を提供するため 3),4)，河川整備や樹木整備の効果を地先スケールで照査 し，河道改修計画の立案等に供することができる．一方， 河川改修を的確に進めるためには，樹林化の要因を明ら かにすることが必要であり，水文・地形・植生の経年変 化ならびに流水攪乱効果に及ぼす河道改修の影響を分析 しなければならない，樹林区間だけではなく改修・樹林 改変の影響が及ぶ上下流方向を視野に入れること，単発 の出水イベントだけではなく中長期的な水文トレンドを 見極めることなど，二次元モデルでは取扱にくい大きな 時空間規模を対象とできる解析ツールが必要である. 河 道整備の初期工程では，断面情報から [流量〜（水位， 流速）] の関係を求め, 洪水流量と河道・植生条件に対 する水位・流速を推算することが必要である.

そこで本研究では, 植生の流水抵抗を考慮した等流 解析 (5)加古川へ適用することによって, 河道地形や流 量の経年変化が高水敷の冠水頻度と樹林一の流水攪乱に 及ぼす影響を分析し，樹林化の要因を明らかにする．さ らに, 高水敷切り下げと間伐が流水による樹木倒伏一及 
ぼす影響を評価し，［河川整備，樹木管理］の適正な組 み合わせによる省力的な維持管理戦略を提案する.

\section{2. 対象区間の概要}

一級水系加古川の直轄区間（河口〜河口距離 $36.4 \mathrm{~km}$ ）を対象とする. 当該区間の地形はセグメント 2.1 に分類され，ヤナギなどの樹木と草本が繁茂してい る. 図-1に示す各地点の横断面に着目し，1967 2009年 における地形の変遷と河道内樹林化との関連性を分析す る. $23.6 \mathrm{~km}$ 地点では，高水敷が試験的に切り下げられ ており，著者らは流速・水位や樹林状況の集中観測と出 水時の流況解析を2008年より継続している2),6).

\section{3. 樹林化した河道の流れと流体力の解析}

塩野らは台形複断面水路の等流を対象に植生抵抗を考 慮した流速分布の解を得た7)。彼らはDarcy-Weisbachの 摩擦損失係数持用いて厳密解を得ているが，ここでは マニングの粗度係数 $n$ にって基礎方程式を式(1)のよう に再記述し, さらに植生抵抗に関して, 著者らが二次元 解析で用いたモデルを適用した.

$$
\begin{aligned}
& \rho g S_{0} H-\rho \frac{g n^{2}}{H^{1 / 3}}\left(\frac{u_{s}}{p}\right)^{2} \sqrt{\frac{1}{s^{2}}+1}+ \\
& \text { 重力項 河床・㵎㲽に作用する壁面せん断力 } \\
& \frac{\partial}{\partial \mathrm{y}}\left\{\rho \lambda H^{2}\left(\frac{g n^{2}}{H^{1 / 3}}\right)^{1 / 2}\left(\frac{u_{s}}{p}\right) \frac{\partial}{\partial \mathrm{y}}\left(\frac{u_{s}}{p}\right)\right\}= \\
& \text { 水深平均のレイノルズ応力 (内部せん断力) } \\
& \frac{\rho C_{\mathrm{D}} \lambda_{\mathrm{veg}}}{2} u_{s}^{2} H \\
& \text { 檘木に作用する流水抵抗力（榯木に作用する流体力） }
\end{aligned}
$$

ここで， $\rho$ : 水の密度， $g$ : 重力加速度， $y$ : 横断方向座標, $S_{0}$ : 河床の縦断方向勾配， $H$ : 水深， $n$ : マニングの粗度 係数， $u_{\mathrm{s}}$ : 見かけ流速， $p$ :間隙率， $1 / s$ : 横断面各部の河 床の横断方向勾配， $\lambda$ : 無次元渦動粘性係数（本研究で は $\lambda=0.3 ）, C_{\mathrm{D}}$ ：樹木の抗力係数， $\lambda_{\mathrm{veg}}$ : 樹木密生度であ る. 樹林帯領域は見かけ流速 $u_{\mathrm{s}}$ を用いて記述されており， 間隙率 $p$ (単位面積当たりの樹木の投影面積の割合 $r_{\mathrm{A}}$ よ り $P=1-r_{\mathrm{A}}$ と定義される）を考慮して実流速 $u=u_{\mathrm{s}} / p$ と定義 される（本研究では $p \fallingdotseq 1$ とみなす）。 $C_{\mathrm{D}}$ に関しては, $\mathrm{Nepf}^{8)}$ より樹径 $d$ と密生度 $\lambda_{\text {veg }}$ の関数として表される.

式(1)を所定の水深のもとで積分し断面内の流速分布 を得る. さらに，流速と水深から流量が得られる. ここ

\begin{tabular}{|c|c|c|c|c|c|c|c|c|}
\hline & \multicolumn{2}{|c|}{$\begin{array}{c}\text { 河口距離 } \\
(\mathrm{km})\end{array}$} & (1) 4.0 & (2) 19.0 & (3)21.2 & (4) 22.6 & (5) 23.6 & (6) 29.0 \\
\hline \multirow{2}{*}{ 植生条件 } & \multicolumn{2}{|c|}{$\begin{array}{c}\text { 樹林密生度 } \\
\lambda_{\text {veg }}\left(\mathrm{m}^{-1}\right)\end{array}$} & \multicolumn{6}{|c|}{0.01} \\
\hline & \multicolumn{2}{|c|}{ 樹径 $d(\mathrm{~m})$} & \multicolumn{6}{|c|}{0.20} \\
\hline \multirow[t]{2}{*}{ 水理条件 } & \multicolumn{2}{|c|}{$\begin{array}{c}\text { 流量 } \\
Q\left(\mathrm{~m}^{3 / \mathrm{s}}\right)\end{array}$} & $\begin{array}{l}1,500 \\
10,000 \\
\end{array}$ & $\begin{array}{r}1,500 \\
8,000 \\
\end{array}$ & $\begin{array}{r}1,500 \sim \\
8,000 \\
\end{array}$ & $\begin{array}{c}, 000 \sim \\
6,500 \\
\end{array}$ & $\begin{array}{c}1,000 \sim \\
6,500 \\
\end{array}$ & $\begin{array}{c}1,000 \sim \\
5,000 \\
\end{array}$ \\
\hline & \multicolumn{2}{|c|}{$\begin{array}{c}\text { 河床勾配 } \\
S_{0}\end{array}$} & $1 / 1050$ & $1 / 750$ & $1 / 750$ & $1 / 800$ & $1 / 800$ & $1 / 1000$ \\
\hline \multirow[t]{3}{*}{ 河道条件 } & \multirow{3}{*}{$\begin{array}{l}\text { マニングの } \\
\text { 粗度係数 } \\
n\left(\mathrm{~m}^{-1 / 3} \mathrm{~s}\right)\end{array}$} & 低水路 & 0.028 & 0.028 & 0.028 & 0.028 & 0.028 & 0.028 \\
\hline & & \begin{tabular}{|l} 
高水敷 \\
\end{tabular} & 0.027 & 0.028 & 0.034 & 0.055 & 0.055 & 0.073 \\
\hline & & \begin{tabular}{|l} 
樹林带 \\
\end{tabular} & 0.027 & 0.028 & 0.031 & 0.031 & 0.031 & 0.031 \\
\hline
\end{tabular}
では所定の流量に対する流速分布を求める必要があるた め, 流速分布の積分から得られる流量が所定流量になる ような水深をNewton法によって求め, その流速分布を 解として採用している.

表-1 解析条件

図-1 解析対象断面と観測所の位置

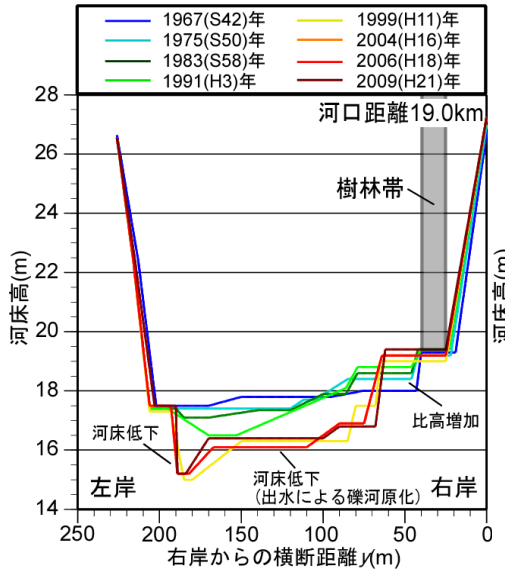

(a) 河口距離 $19.0 \mathrm{~km}$

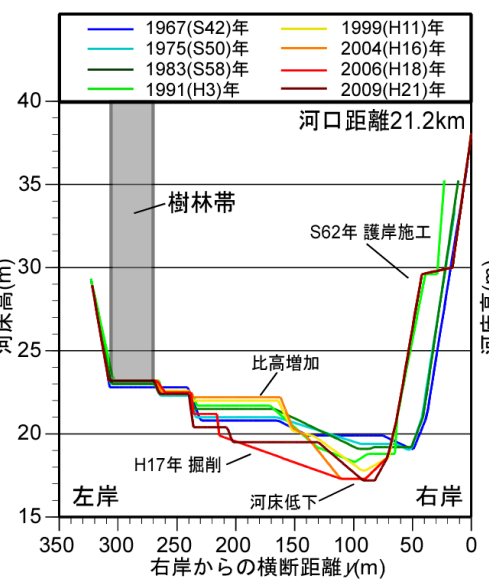

(b) 河口距離 $21.2 \mathrm{~km}$

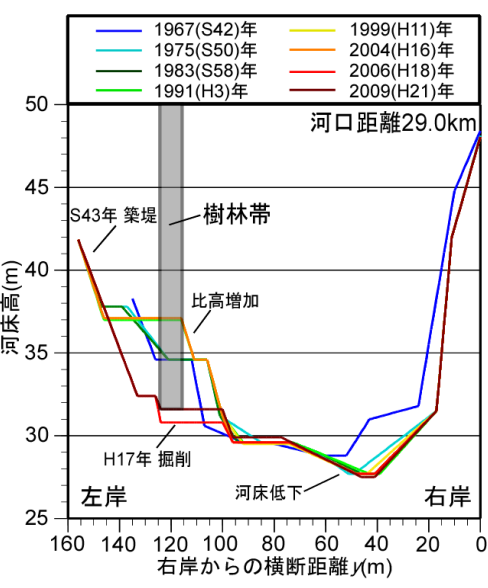

(c) 河口距離 $29.0 \mathrm{~km}$

図-2 河道横断面地形の経年変化 


\section{4. 河道の樹林化をもたらす要因}

1967年，1975年，1983年，1991年，1999年，2004年， 2006年，2009年における(1)～(6)（図-1）の横断面地形を 対象として, 河川流の経年変化を等流解析で分析し, 樹 林化の要因を明らかにする. 各断面の解析条件を表-1に 示す．ここでは，河川地形が流況に及ぼす影響を検討す ることを目的としていることと，樹林の詳細情報がない ことから，高水敷上の樹林帯の位置・密生度・樹径を同 一としている. 航空写真からは, 特に1990年代以降に樹 林が現在とほぼ同程度の密生度に至っているようである。 また，マニングの粗度係数には高水敷整備や植生の影響, 樹林による草本類の成長阻害を考慮して評価された数值 を与えている.

\section{（1）河道地形・流量の経年変化}

図-2(a) (c)に19.0，21.2，29.0kmの横断面地形の経年 変化を示す. 図-2から, いずれの断面においても, 低水 河床が低下し高水敷が上昇するという地形変化が一方的 に進み，「高水敷一低水路」間の地盤高低差は経年的に 増加している. 図-3に高水敷の比高（樹林帯が位置する 高水敷と低水路最深部との標高差）の経年変化を示す. ほとんどの断面で比高が経年的に増加している.ただし， $29.0 \mathrm{~km}$ 地点（6)）に関しては，2004年の台風第23号災 害の復旧工事によって大幅に高水敷が掘削され, 他の地 点よりも比高が大きく減少した。また，23.6kmでは 2008年に高水敷を試験的に切り下げたため，29.0kmほ どではないが，直近の比高は減少している.

約40年間の地形変化を見る限り，ほぼ全ての地点で高 水敷の冠水頻度が減少し, 河川地形の変化が樹林化の直 接的誘因である可能性が高い.

図-1に示す各観測所における年最大流量の経年変化を 図-4に示す．なお，流況の豊水・平水・低水・渇水流量 に関しても同様に検討したが，有意な経年変化が見出さ れなかったため, 高水敷の冠水流量の目安となる年最大 流量に着目した. (1)〜6)の地点はいずれも流量観測所の 近傍に位置しているが，22.6km（4)）と23.6km（5) に関しては，観測所が近くになく，大島・万願寺両観測 所の観測值を用いて流量を推算した. 図-4に示すいずれ の地点に関しても年最大流量の経年的変化は認められな い. ダムの下流で樹林化が進行するような他の河川とは 異なり, 流量の人為制御や水文事象の变化が樹林化の要 因とは考えられない.

\section{（2）流速分布の解析例}

それぞれの地点の計画高水相当の流量に対する流速分 布の経年変化を等流解析によって求めた。例として $19.0 \mathrm{~km}$ 地点 $\left(Q=6000 \mathrm{~m}^{3} / \mathrm{s}\right)$ と $29.0 \mathrm{~km}$ 地点 $\left(Q=3800 \mathrm{~m}^{3} / \mathrm{s}\right)$ の流速分布を図-5(a)，(b)に示す．樹林 部の流速低減の様子が再現されている. 先に示した河道 地形の経年変化に応じて, 低水路の流速は年々増加し, 高水敷の流速は徐々に低減している．ただし，1967，75， 83年などでは，ここで設定したほど樹林は発達していな

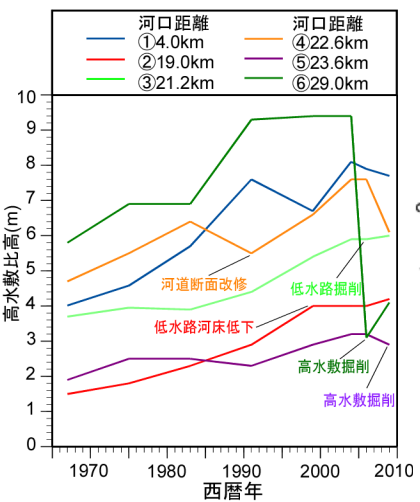

図-3 高水敷比高の経年変化

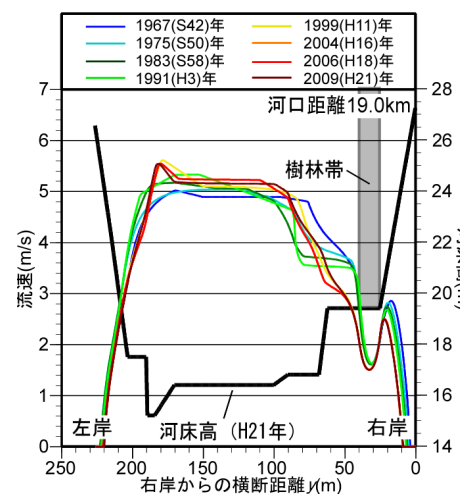

(a) 河口距離 $19.0 \mathrm{~km}$

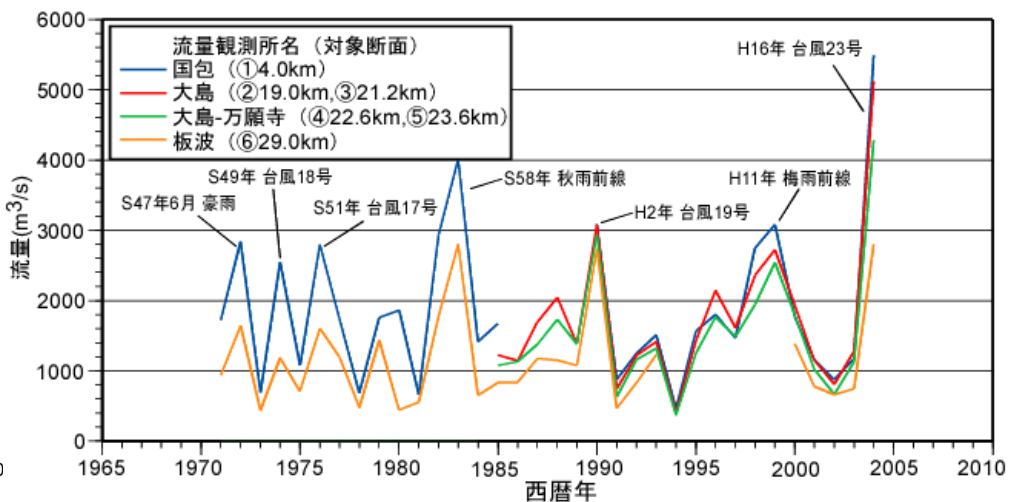

図-4 年最大流量の経年変化

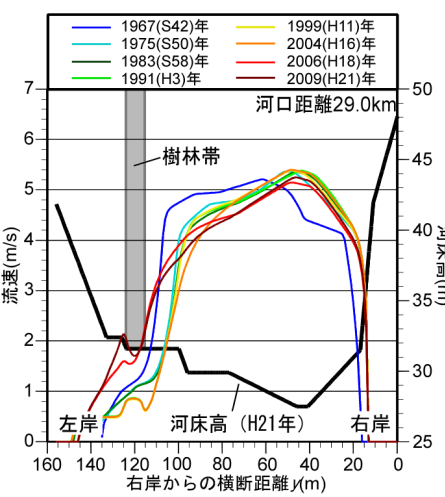

(b) 河口距離 $29.0 \mathrm{~km}$ 
いと考えられ，ここで示す以上に大きな流水攪乱によっ て樹林化が抑制されていたと想像できる．29.0 km地点 を見ると, 前述の災害復旧工事（2005年）による高水敷 切り下げなどの影響で高水敷の流速が回復しているが, その他のほとんどの地点で流速は低水路で増加し高水敷 で減少するという経年変化が認められる.

\section{（3）高水敷が冠水する流量}

高水敷の樹林帯が冠水するために必要な流量を各地点 の等流解析に基づいて算定した（以降，「冠水流量」と 略記）. 図-6に示すように，いずれの地点でも冠水流量 は経年的に増加している. このように, 高水敷が冠水し て樹木が流水攪乱を受ける頻度は年々減少し, 樹林化を 促進している可能性が高い.

\section{（4）倒伏モ一メントの経年変化}

図-7(a) (f)には各地点での樹木の倒伏モーメント比 $M_{\mathrm{v}} / M_{\mathrm{c}}$ を各年の地形と様々な流量に対して等流解析から 求め, 西暦年と流量との関係としてあらわす。ここで $M_{\mathrm{v}} / M_{\mathrm{c}}$ とは, 樹木一本あたりに作用寸る流体力の倒伏 モーメント $M_{\mathrm{v}}$ とその限界值 $M_{\mathrm{c}}\left(M_{\mathrm{c}}=245000 d^{2}\right){ }^{9)}$ との比 として定義され, $M_{\mathrm{v}} / M_{\mathrm{c}}>1$ の時, 樹木は倒伏寸ると考え る. 図-7(a) (f)から, 各地点とも $M_{\mathrm{v}} / M_{\mathrm{c}}$ が経年的に低減 し, 樹木倒伏の可能性は減少している. また, $23.6 \mathrm{~km}$ 地点での高水敷の試験的切り下げ（2008年），29.0km 地点での災害復旧工事による高水敷切り下げ (2005年) により，それぞれの地点での $M_{\mathrm{v}} / M_{\mathrm{c}}$ が増大していること が図-7(e), (f)からわかる。これに対し，例えば図-7(b), (c)に示す $19.0 \mathrm{~km}$ 地点では1999年以降の高水敷の低下, $21.2 \mathrm{~km}$ 地点では2005年の高水敷切り下げによって樹林 帯の冠水頻度が減少し, $M_{\mathrm{v}} / M_{\mathrm{c}}$ が低下している. 図-7(a) (f) の $M_{\mathrm{v}} / M_{\mathrm{c}}$ と図-6の冠水流量の経時変化挙動 は類似している. 比高とともに冠水流量が増加し, $M_{\mathrm{v}} / M_{\mathrm{c}}$ を経年的に減少させることが樹林化の要因である ことが判明した.

\section{5. 高水敷の切り下げと間伐を組み合わせた河川 管理戦略について}

集中観測と二次元解析を継続している河口距離 23.6km地点を対象に，2009年時点の河川地形と樹林状 況を基淮として，高水敷をさらに切り下げた場合と樹林 を間伐した場合の $M_{\mathrm{v}} / M_{\mathrm{c}}$ を等流解析から求め，［河川整 備，樹木管理」を組み合わせた河川管理戦略を考える.

\section{（1）想定する河道断面と樹林密度}

現状より高水敷を $\Delta z=0.25 \sim 1.5 \mathrm{~m}$ 切り下げた場合，なら びに樹林の間伐を想定して密生度を $\lambda_{\mathrm{veg}}=0.05 \sim 0.005 \mathrm{~m}^{-1}$ に 低減させた場合を考える（図-8参照）。その他の解析条 件は表-1の $23.6 \mathrm{~km}$ と同様である. なお，樹径 $0.2 \mathrm{~m}$ は樹齢 12年相当であるが，本解析では切り下げ後に樹木が流水 攪乱を受けることなく再繁茂した状態を仮想的に設定し て樹木の条件を与えている.

\section{（2）高水敷切り下げと間伐が流速と倒伏モ一メントにお よぼす効果}

図-9(a), (b)に切り下げ量 $\Delta z$ (密生度 $\lambda_{\text {veg }}=0.01 \mathrm{~m}^{-1}$ ) と樹 林密生度 $\lambda_{\text {veg }}$ （現況断面）が流速分布に及ぼす影響を $Q=4,900 \mathrm{~m}^{3} / \mathrm{s}$ （計画流量相当）の場合について例示する. ここで, 高水敷の状態は施工直後の裸地ではなく, 草本 などで覆われ現状程度の粗度状態 $\left(n=0.055 \mathrm{~m}^{-1 / 3} \mathrm{~s}\right)$ と考 えている. 高水敷の切り下げによって低水路より粗度の

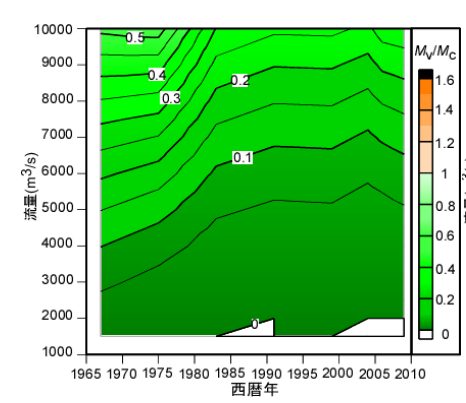

(a) 河口距離 $4.0 \mathrm{~km}$

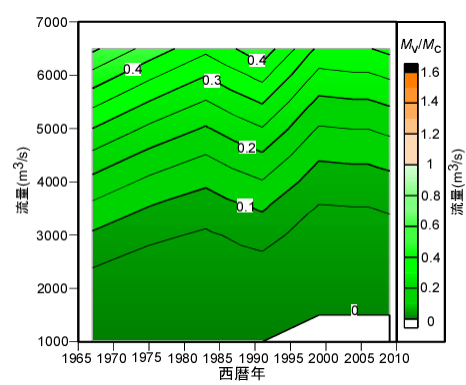

(d) 河口距離22.6km

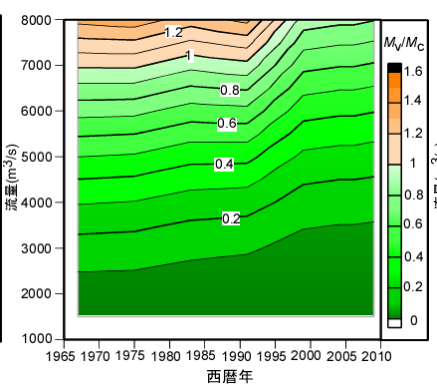

(b) 河口距離 $19.0 \mathrm{~km}$

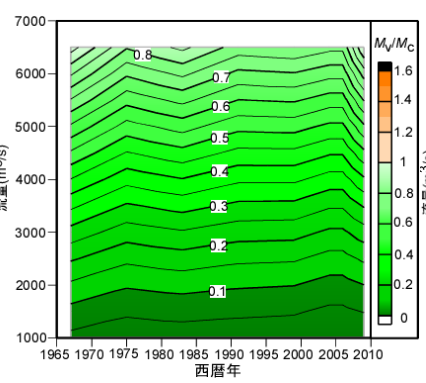

(e) 河口距離 $23.6 \mathrm{~km}$

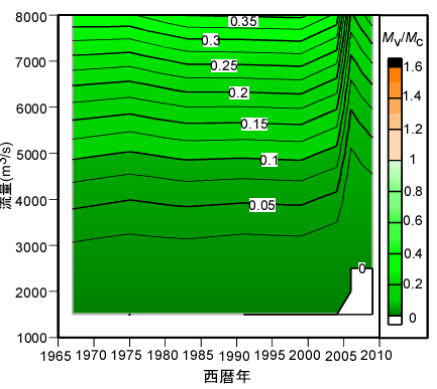

(c) 河口距離 $21.2 \mathrm{~km}$

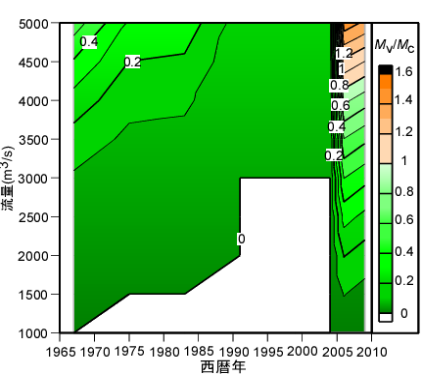

(f) 河口距離 $29.0 \mathrm{~km}$

図-7 倒伏モーメント比の経年変化 
大きな高水敷が拡がり断面積が増加するため, 水際領域 の流速は低減する（図-9(a)）。また，密生度の増加に ともなう流速低減の様子も確認される（図-9(b)）。

そこで，樹木の倒伏モーメント比 $M_{\mathrm{v}} / M_{\mathrm{c}}$ を，(a) $[\Delta z, Q]$ $\left(\lambda_{\text {veg }}=0.01 \mathrm{~m}^{-1}\right)$, (b) $\left[\lambda_{\text {veg, }} Q\right]$ (現況断面) , (c) $\left[\Delta z, \lambda_{\text {veg }}\right]$ $\left(Q=4,900 \mathrm{~m}^{3} / \mathrm{s}\right)$ の関数として，図-10(a) (c)にそれぞれ， 示す. 図-10(a), (b)から, 高水敷の切り下げあるいは間 伐（密生度の減少）をそれぞれ単独施工したいずれの場 合にも $M_{\mathrm{v}} / M_{\mathrm{c}}$ が増加することが確認される. 切り下げ・ 間伐の単独施工の場合, 樹木倒伏を期待できる $M_{\mathrm{v}} / M_{\mathrm{c}}>1$ の条件が達成されるためには, 計画流量 $Q=4,900 \mathrm{~m}^{3} / \mathrm{s}$ よ りも相当大きな流量を必要とする. これに対し, 切り下 げと間伐の組み合わせを想定した図-10(c)を見ると計画 洪水流量程度でも樹木倒伏を期待できる. これは, 密生 度の減少が樹木への倒伏モーメントを増加させるためで ある。しかし，計画規模の流水攪乱に対してしか樹木倒 伏を期待できないとも言え, 自然営力を利用した樹林化 抑制が困難であることを示唆している. より生起確率の 高い小規模出水でも攪乱効果を発揮するためには，現状 より幼木の段階で間伐・伐木により密生度 $\lambda_{\text {veg }}$ を下げる ような樹林管理が水理学的観点からは有効である.ただ し, 間伐による成長促進が倒伏限界モーメントを増加さ せる可能性もあるので，樹林の管理に際しては植物生態 学の観点も必要である.

前述のように，対象地点では流水攪乱による繁茂抑制 を目的として2008年に高水敷が約1m切り下げられたが, 1 年後にはヤナギ稚樹の再繁茂が確認された. 高水敷の 切り下げによって土㙵水分がヤナギ活着の好適水淮にま で増加し，栄養繁殖をかえって促進したようである．今
後, 樹木の成長とともに流水抵抗・倒伏モーメントが増 加し, 高水敷の切り下げによる流水攪乱効果の発現を期 待できるが，切り下げと間伐の水理学的効果だけではな く, 土㙥水分など樹木の生態特性におよぼす物理環境も 樹木管理に重要な視点であることが示唆される.

図-10(c) と同様の解析を様々な流量規模に対して実施 し, 流量の生起確率（約30年間の流量時系列に基づく） から得られる $M_{\mathrm{v}} / M_{\mathrm{c}}$ の期待値 $D_{\mathrm{E}}$ を次式で算出する.

$$
D_{E}=\sum_{T=1}^{n} D(T) \cdot p(T) d T
$$

ここで, $D(T)$ : 再現期間が $T$ 年の流量に対する $M_{\mathrm{v}} / M_{\mathrm{c}}$, $p(T)=1 / T-1 /(T+1):$ 年規模の流量の生起確率密度である.

図-11に $D_{\mathrm{E}}$ と $\left[\Delta z, \lambda_{\text {veg }}\right]$ との関係を示す. $D_{\mathrm{E}}$ に対する切 り下げ量 $\Delta z$ の効果は線形的であるのに対し, 密生度に 関しては $\lambda_{\text {veg }}$ の減少とともに非線形的に $D_{\mathrm{E}} か ゙$ 増加し, 密 生度の低い範囲で流水攪乱による樹木倒伏の効果が高い ことがわかる. 例えば, $1.5 \mathrm{~m}$ の高水敷切り下げの下で は密生度が $\lambda_{\text {veg }}=0.05 \mathrm{~m}^{-1}$ である場合に比べ, $\lambda_{\text {veg }}=0.005 \mathrm{~m}^{-1}$ まで間伐した場合に $D_{\mathrm{E}}$ が五倍程度にまで増加する。し たがって，高水敷を切り下げた後に，間伐によって樹木 の新規参入を抑制することが特に重要である.

\section{（3）二次元モデルによる切り下げと間伐の効果の確認}

二次元二層流モデル2)を河口距離23.0 24.4kmの区間

（図-12）に適用し，高水敷切り下げや間伐が樹木倒伏 に及ぼす影響を確認する。本モデルは樹冠を通る内部境 界面で河川流を上下二層に分割し，樹林帯周辺の鉛直・ 水平方向の流速差・内部せん断力を表現するモデルであ る. 表-2の解析条件の下で, 図-12の切り下げエリアに

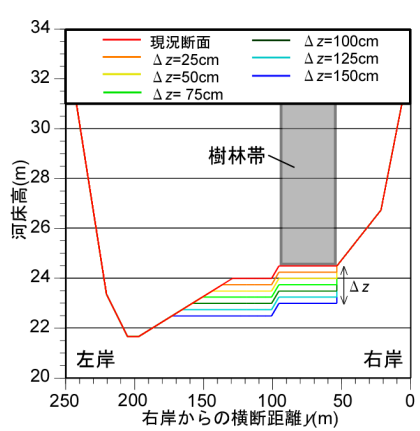

図-8 23.6km地点横断地形

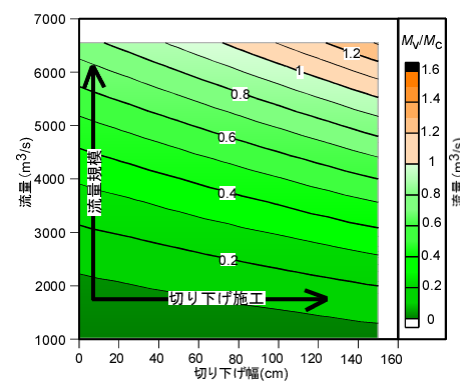

(a) 切り下げ $\Delta z$ 効果 $\left(\lambda_{\text {veg }}=0.01 \mathrm{~m}^{-1}\right.$ : 現状 $)$

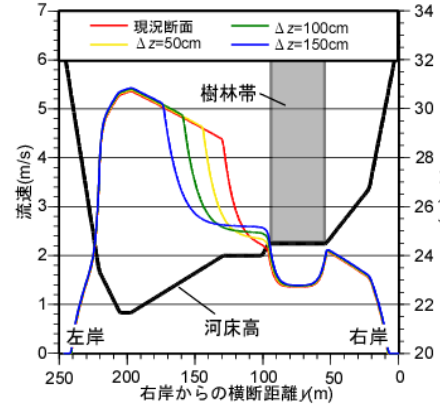

(a) 高水敷切り下げ $\Delta z$ の影響

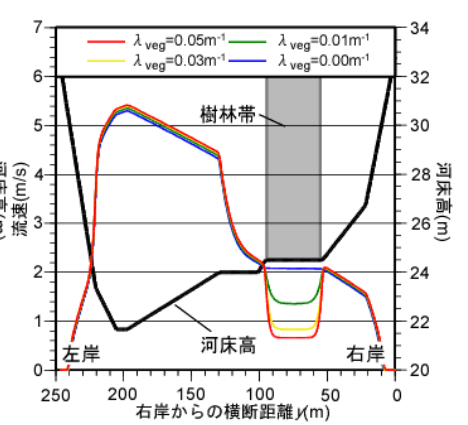

(b) 密生度 $\lambda_{\text {veg }}$ の影響

図-9 流速分布の変化 $\left(Q=4900 \mathrm{~m}^{3} / \mathrm{s}\right.$ の場合 $)$

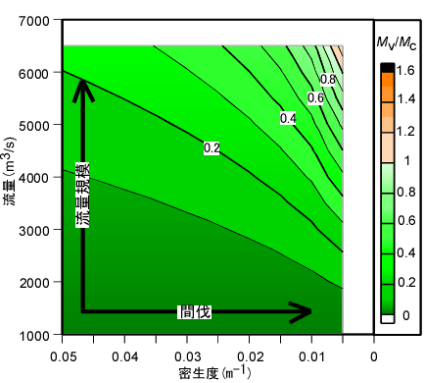

(b) 間伐 $\lambda_{\text {veg }}$ の効果 (現況断面)

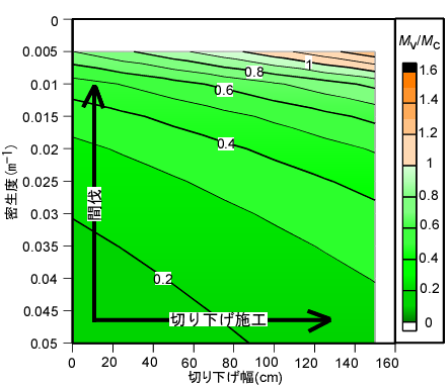

(c) 切り下げ $\Delta z$ 間伐 $\lambda_{\text {veg }}$ の効果 $\left(Q=4,900 \mathrm{~m}^{3} / \mathrm{s}\right)$ 図-10 切り下げ $\Delta z$ 間伐 $\lambda_{\text {veg }}$ の倒伏モ一メント比 $M_{v} / M_{\mathrm{c}}$ におよぼす影響 


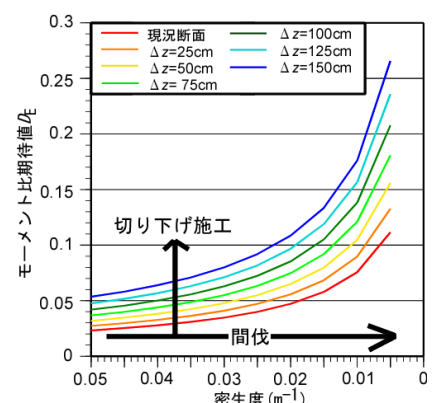

図-11 倒伏モーメント比の期待値

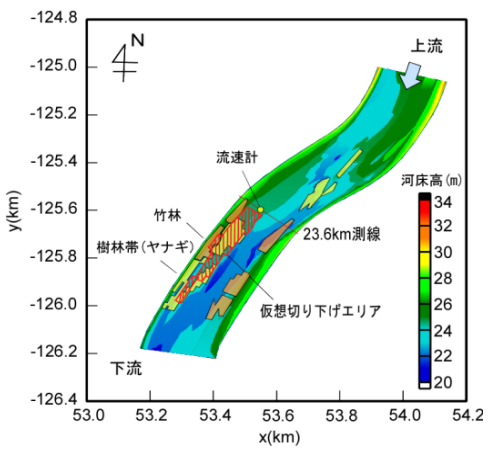

図-12 解析対象地形図

おける $\Delta z=0.25 \sim 0.5 \mathrm{~m}, \lambda_{\text {veg }}=0.02 \sim 0.005 \mathrm{~m}^{-1}$ に対する倒伏 率 $D$ (次式)を算定する。

$$
D=100 \times A_{\mathrm{D}} / A_{\mathrm{V}}
$$

ここで， $A_{\mathrm{D}}$ :樹林倒伏面積， $A_{\mathrm{V}}$ :樹林繁茂面積である.

図-13(a), (b)に $D$ と $\left[Q, \Delta z, \lambda_{\text {veg }}\right]$ との関係を示す.

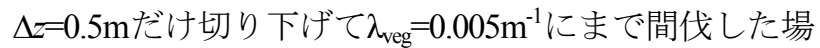
合には，Dの増加が顕著である。これらは，等流解析か ら得られた結果と同様であり, 切り下げと間伐の組み合 わせ施工の重要性が再確認される。

\section{6. おわりに}

本論では，植生を考慮した等流解析に基づき，高水敷 切り下げと間伐が樹林一作用する流水攪乱に及ぼす影響 を明らかにした。

・流量や河川地形および等流解析による倒伏モーメント 比の経年変化から，流量の有意な経年変化は加古川では 見られず，河川地形の人為的・自然的変化にともなう高 水敷の冠水頻度の減少が樹林化の主たる要因であること を明らかにした。

・高水敷の切り下げと間伐を想定した感度解析によって, これらの施工が樹木倒伏率におよぼす影響を定量的に示 した. これにより，高水敷切り下げなどの河道改修と間 伐・伐採などの樹木管理を適切に組み合わせることの有 效性を確認した.

謝辞 : 現地観測に際しては, 神戸大学宮本仁志氏，同 大学と明石高専の学生諸君にご協力頂いた. また, 本研
表-2 解析条件

\begin{tabular}{|c|c|c|c|}
\hline 流量 $Q\left(\mathrm{~m}^{3} / \mathrm{s}\right)$ & 322 & & 4500 \\
\hline 下流端水位 $H(\mathrm{~m})$ & \multicolumn{2}{|c|}{29.3} & 30.6 \\
\hline ングの粗度係数 $n\left(\mathrm{~m}^{-1 / 3} \mathrm{~s}\right)$ & 低水路 & 0.028 & 高水敷 : 0.055 \\
\hline 樹高 $H_{v}$ ，樹径 $\mathrm{d}(\mathrm{m})$ & & 8.0 & 0.2 \\
\hline
\end{tabular}

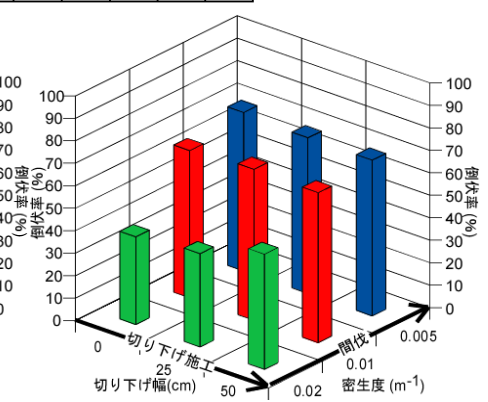

(b) 流量 $4500\left(\mathrm{~m}^{3} / \mathrm{s}\right)$ (a) 流量 $3220\left(\mathrm{~m}^{3} / \mathrm{s}\right)$

図-13切り下げと間伐による倒伏率の変化

究の一部は科学研究費補助金基盤研究(B)「河道内樹林 の消長機構に関する水理・生態学的解析と持続的河川管 理に向けた戦略研究」(課題番号 : 23360212, 平成2325年度，代表者 : 道奥康治），平成22年度河川整備基金 助成事業「水文確率特性と樹木生態・伐採を考慮した河 道内樹林の消長解析と河川管理一の適用」（助成番号： 22-1212-011）の支援の下に実施された。 以上，記して 謝意を表する.

\section{参考資料}

1) 辻本哲郎・村上陽子 : 出水による破壊機会の減少による河 道内樹林化，水工学論文集，第45巻，pp.1105-1110， 2001.

2) 道奥康治・宮本仁志・神田佳一・大地洋平 : 樹林が繁茂し た加古川中流部における出水時流況と樹林損壊に関する調査・ 解析，水工学論文集，第55巻，pp.S_1087-S_1092， 2011.

3）前野詩朗・宮内洋介・森卓也 : 植生が旭川の洪水流に及ぼ す影響の検討，水工学論文集，第48巻，pp.757-762， 2004.

4) 清水義彦・小葉竹重機・新船隆行 : 樹林化河道の洪水流況 と浮遊砂輸送に関寸る数值計算, 水工学論文集, 第44巻, pp.819-824, 2000.

5)P.Pameshwaran and K.Shiono: Quasi two-dimensional model for straight overbank flows through emergent vegetation on floodplain, J.Hydraul.Engrg., Vol.45, pp.302-315, 2007.

6) 宮本仁志 - 盛岡淳二・神田佳一・道奥康治 : 流量変動のイ ンパクトを考慮した河道内樹林動態の確率モデル，水工学論文 集，第55巻, pp.S_1405-S_1410, 2011.

7) K.Shiono and D.W.Knight: Turbulent open-channel flows with variable depth across the channel, J.Fluid Mech., Vol.222, pp.617646, 1991.

8) H.M.Nepf : Drag, turbulence, and diffusion in flow through emergent vegetation, Water Resources Research, Vol.35-2, pp.479-489, 1999.

9) (財)リバーフロント整備センター編 : 河川における樹木管理 の手引き, 山海堂, pp.157, 1999.

(2011. 9. 30受付) 